JBTI : Jurnal Bisnis : Teori dan Implementasi

ISSN Cetak: 2085-7721, ISSN Online: 2622-0733

Website : http://journal.umy.ac.id/index.php/bti

Vol 11, No 1 (2020): April 2020 Hal. 35-43

\title{
NIAT PENGGUNAAN TEKNOLOGI INFORMASI DAN KOMUNIKASI PADA USAHA MIKRO KECIL MENENGAH DI YOGYAKARTA
}

\author{
Muhammad Muthahhari \\ Universitas Muhammadiyah Yogyakarta \\ Email: muhhari@gmail.com \\ Heru Kurnianto Tjahjono \\ Universitas Muhammadiyah Yogyakarta \\ Email: herukurnianto@umy.ac.id \\ Meika Kurnia Puji RDA \\ Universitas Muhammadiyah Yogyakarta \\ Meika_kurnia@umy.ac.id
}

\begin{abstract}
The aim of this study is to find out behavior institutions in using information and communication technology among Micro Small Medium Enterprise (MSME) in Yogyakarta. Based on unified theory of Acceptance and Use of Technology (UTAUT) model. This study examine whether performance expectancy, effort expectancy, and social influence are the importance antecedent to explain intentions in using ICT (Information and communication technology) among MSME. This study also examine the effect of propensity to act as the moderator in model. There are 164 MSME owners in Yogyakarta as a sample of this study which used purposive technique and analyzed by SEM. The result of this study showed that the performance expectancy and effort expectancy are supported to explain intention use ICT in MSME. Therefor, social influence does not has significant to predict intentios use ICT. The other findings showed that propensity to act has moderation effect on the relation between performance expectancy, effort expectancy, and social influence and behavior intentions.
\end{abstract}

Key words: TIK; UTAUT; MSMEs.

Abstrak: Tujuan dari penelitian ini adalah untuk mengetahui perilaku institusi dalam menggunakan teknologi informasi dan komunikasi antara Usaha Mikro Kecil Menengah (UMKM) di Yogyakarta. Berdasarkan teori Unified of Acceptance and Use of Technology (UTAUT) model. Penelitian ini menguji apakah ekspektasi kinerja, ekspektasi upaya, dan pengaruh sosial adalah anteseden yang penting untuk menjelaskan niat dalam menggunakan TIK (teknologi informasi dan komunikasi) di kalangan UMKM. Penelitian ini juga menguji pengaruh kecenderungan untuk bertindak sebagai moderator dalam model. Ada 164 pemilik UMKM di Yogyakarta sebagai sampel penelitian ini yang menggunakan teknik purposive dan dianalisis dengan SEM. Hasil penelitian ini menunjukkan bahwa ekspektasi kinerja dan ekspektasi upaya didukung untuk menjelaskan niat menggunakan TIK dalam UMKM. Oleh karena itu, pengaruh sosial tidak signifikan untuk memprediksi intensitas menggunakan TIK. Temuan lain menunjukkan bahwa kecenderungan untuk bertindak memiliki efek moderasi pada hubungan antara harapan kinerja, harapan usaha, dan pengaruh sosial dan niat perilaku.

Kata Kunci: TIK; UTAUT; MSMEs.

Article History: Received 2020-02-06; Revised 2020-04-16; Accepted 2020-04-20

Muhammad Muthahhari ${ }^{1}$, Heru Kurnianto Tjahjono ${ }^{2}$, Meika Kurnia Puji RDA ${ }^{3}$ - Niat Penggunaan Teknologi Informasi Dan Komunikasi... [Vol 11, No 1 (2020): April 2020] JBTI 


\section{PENDAHULUAN}

Dalam beberapa tahun terakhir, struktur ekonomi dan sosial telah mengalami beberapa perubahan penting, terutama karena pesatnya kemajuan Teknologi Informasi dan Komunikasi (TIK). Pengguna internet di Indonesia mencapai 63,5\% dari total populasi atau total 171,26 juta orang (Internet World Stats, 2019). Tingginya pertumbuhan pengguna internet juga berkontribusi terhadap aktivitas ekonomi yang ditunjukkan oleh persentase pembelian online per pengguna internet aktif yang mencapai $78 \%$.

Ada tiga dampak signifikan yang dimiliki TIK terhadap dunia bisnis. Pertama, peningkatan kecepatan, akses, dan peluang bagi konsumen. Konsumen saat ini dapat mengakses berbagai layanan pada satu platform dan memiliki kesempatan untuk mendapatkan informasi lebih lanjut tentang suatu produk. Kedua, cara baru melakukan intelijen bisnis. Melalui TIK, pemilik bisnis dapat memperoleh wawasan baru tentang konsumen yang mungkin belum pernah diperoleh sebelumnya. Pemilik bisnis juga dapat mengetahui opini publik tentang produk dan perilaku konsumen mereka sehingga mereka dapat meningkatkan kualitas layanan dengan cepat dan akurat. Ketiga, infrastruktur digital membuat infrastruktur fisik tidak relevan. Ini dapat memungkinkan perusahaan untuk menghemat lebih banyak uang (DBS Group Research, 2014).

Kegiatan ekonomi berbasis TIK membuka peluang baru bagi UKM. Di era perdagangan online dan globalisasi ekonomi saat ini TIK digunakan untuk mendukung kebutuhan bisnis, terlepas dari ukuran bisnis. Ketidakmampuan untuk menggunakan TIK akan mengurangi daya saing perusahaan dan kehilangan peluang untuk berkembang (Hashim, 2007). Dengan mengadopsi TIK, UMKM memiliki peluang untuk mengimbangi kelemahan kompetitif dalam hal ukuran, sumber daya, isolasi geografis, dan jangkauan pasar (Wymer \& Regan, 2005).

Menurut Bank Dunia, sektor UMKM adalah tempat di mana ekonomi rakyat bergantung dengan menyumbang 56 persen dari total ekonomi negara. Pemerintah Indonesia kini telah mengambil langkah-langkah untuk mempercepat digitalisasi melalui program Kementerian Koperasi dan UKM yang menargetkan 8 juta pengusaha UKM untuk online pada tahun 2019. Program ini dilakukan berdasarkan data Kementerian Koperasi dan UMKM mengenai jumlah UKM yang menggunakan TIK seperti e-commerce yang baru mencapai 3,79 juta unit. Artinya UMKM masih jauh tertinggal dalam pemanfaatan TIK.

Upaya peningkatan adopsi teknologi pada UMKM memerlukan wawasan mengenai variabel yang berpengaruh terhadap perilaku tersebut. Adopsi teknologi di berbagai bidang telah menjadi topik yang banyak diangkat dalam studi sistem informasi manajemen. Minat penelitian dalam topik tersebut sebagian besar didorong oleh asumsi dasar bahwa TIK menawarkan peluang baru bagi suatu organisasi. Untuk itu penelitian ini berfokus pada niat menggunakan TIK untuk bisnis pada UMKM sehingga model yang digunakan dalam penelitian ini terkait dengan penggunaan teknologi. Selain itu penelitian ini mencoba menggali faktor kewirausahaan yang turut mempengaruhi niat UMKM dalam penggunaan TIK dari model potensi kewirausahaan dengan variabel kecenderungan bertindak (propensity to act) sebagai variabel moderasi

\section{KAJIAN TEORI}

Variabel dalam penelitian ini diambil dari model Unified Theory of Acceptance and Use of Technology (UTAUT). Model UTAUT diusulkan oleh Venkatesh et al. (2003) dengan menggabungkan konstruksi model adopsi teknologi sebelumnya. UTAUT dibuat untuk upaya memahami adopsi teknologi individu secara terpadu. Model ini menggunakan variabel berikut sebagai prediktor variabel niat perilaku.

Muhammad Muthahhari ${ }^{1}$, Heru Kurnianto Tjahjono ${ }^{2}$, Meika Kurnia Puji RDA ${ }^{3}$ - Niat Penggunaan Teknologi Informasi Dan Komunikasi... [Vol 11, No 1 (2020): April 2020] JBTI 
Performance Expectancy (PE) didefinisikan sebagai tingkat bagaimana individu percaya bahwa menggunakan sistem akan membantu meningkatkan kinerja pekerjaan mereka. Konstruk berasal dari lima model yaitu perceived usefulness, extrinsic motivation, job-fit, relative advantage dan outcomes expectations (Venkatesh et al., 2003). Penelitian Kohnke et al. (2014) menemukan bahwa performance expectancy berpengaruh positif pada niat dokter dalam menggunakan teknologi telehealth. Hasil penelitian Vrsajkovic (2016) menunjukkan bahwa pembuat keputusan dari organisasi UKM Kroasia bersedia menerima teknologi cloud computing, selama mereka merasa bahwa menggunakan cloud computing akan menguntungkan mereka dan organisasi mereka dengan meningkatkan produktivitas dan efisiensi. Hasil studi sejalan dengan studi Palupi dan Tjahjono (2008) bahwa manfaat dan harapan kinerja berpengaruh pada niat perilaku.

H1: Performance Expectancy memiliki pengaruh signifikan pada niat perilaku untuk menggunakan TIK pada UMKM

Effort Expectancy (EE) didefinisikan sebagai tingkat kemudahan terkait penggunaan sistem. Tiga konstruk diturunkan dari model sebelumnya, yaitu perceived ease of use, complexity, dan ease of use (Venkatesh et al., 2003). Tan et al. (2013) menemukan bahwa effort expectancy memberikan pengaruh signifikan pada niat untuk menggunakan pemasaran internet di antara orang Korea Selatan. Sementara temuan Goswami \& Dutta (2017) effort expectancy secara positif mempengaruhi niat pengusaha perempuan untuk menggunakan ecommerce dalam menjalankan bisnis mereka. Niat mengadopsi aplikasi e-commerce meningkat jika wanita pengusaha memahami bahwa aplikasi e-commerce dapat dengan mudah digunakan.

H2: Effort Expectancy memiliki pengaruh signifikan terhadap niat perilaku dalam penggunaan TIK pada UMKM

Social Influence (SI) didefinisikan sebagai tingkat di mana individu merasa bahwa orang lain yang dia pikir penting berasumsi bahwa dia harus menggunakan sistem baru. Akar konstruk ini berasal dari subjective norms, social factors, dan images (Venkatesh et al., 2003). Hipotesis penelitian adalah sebagai berikut. Fobang et al. (2017) menemukan bahwa social influence mempengaruhi adopsi IT (termasuk HRIS). Begitu juga dengan penelitian Goswami \& Dutta (2017) yang menunjukkan pengaruh sosial secara signifikan mempengaruhi niat perilaku pengusaha perempuan untuk menggunakan e-commerce

H3: pengaruh sosial memiliki pengaruh signifikan terhadap niat perilaku dalam penggunaan TIK dalam UMKM

\section{Efek Moderasi Propensity to Act}

Pada UMKM, pemilik bisnis menghadapi berbagai tantangan dan peluang untuk mengadopsi dan menggunakan inovasi TIK. Meskipun mereka telah memiliki cukup ekspektasi, niat menggunakan TIK belum tentu terbentuk begitu saja. Krueger \& Brazeal (1994) mengemukakan bahwa pilihan pengambilan keputusan tergantung pada kredibilitas relatif dari perilaku alternatif dan beberapa kecenderungan untuk bertindak. Ini berarti bahwa niat harus dibentuk dengan cukup baik untuk memprediksi perilaku, dan itu tidak mungkin tanpa kecenderungan untuk bertindak. Kecenderungan untuk bertindak dapat memengaruhi niat melalui pengaruh pada pengalaman dan sikap masing-masing individu.

Dalam kondisi kecenderungan untuk bertindak rendah, sikap mungkin kurang memprediksi niat dan tindakan. Dalam kondisi kecenderungan bertindak yang tinggi, pengalaman lebih berpengaruh pada sikap dan mengambil tindakan yang lebih diinginkan.

Muhammad Muthahhari ${ }^{1}$, Heru Kurnianto Tjahjono ${ }^{2}$, Meika Kurnia Puji RDA ${ }^{3}$ - Niat Penggunaan Teknologi Informasi Dan Komunikasi... [Vol 11, No 1 (2020): April 2020] JBTI 
Pengaruh sikap terhadap niat menggunakan teknologi telah dibuktikan dalam penelitian tentang niat mahasiswa di Yogyakarta untuk menjadi wirausahawan yang menggunakan IT (Tjahjono dkk., 2013; Tjahjono \& Palupi, 2014). Hasil penelitian menunjukkan bahwa sikap memiliki pengaruh positif terhadap niat melakukan suatu perilaku. Sikap terdiri dari kepercayaan dan evaluasi yang berdampak positif pada niat berperilaku. Dalam hal ini, keyakinan bahwa perilaku memiliki prospek dan produktif bagi individu mendorong mereka untuk lebih bersemangat (memiliki niat kuat) untuk melakukan perilaku tersebut.

Pada penelitian Moghavvemi \& Salleh (2014) propensity to act adalah pengaruh terkuat pada niat untuk menggunakan inovasi TI. Efek positif yang kuat dari kecenderungan untuk bertindak menunjukkan bahwa jika para pengusaha memutuskan untuk menggunakan inovasi TIK, dan mereka bertahan dalam keputusan mereka, kemungkinan untuk menggunakan inovasi TI akan lebih tinggi.

H4: kecenderungan untuk bertindak memoderasi pengaruh ekspektasi kinerja pada niat perilaku untuk menggunakan TIK dalam UMKM

H5: kecenderungan untuk bertindak memoderasi pengaruh ekspektasi upaya pada niat perilaku untuk menggunakan TIK dalam UMKM

H6: kecenderungan untuk bertindak memoderasi pengaruh pengaruh sosial pada niat perilaku untuk menggunakan TIK dalam UMKM

Dari hipotesis di atas, model penelitian berikut diusulkan:

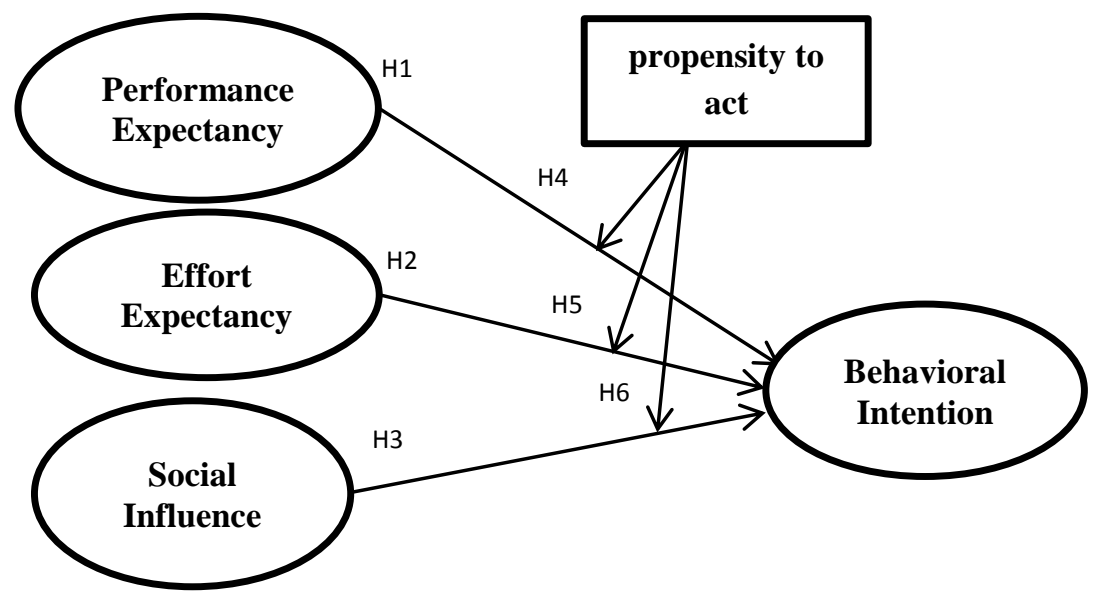

Gambar 1. Model Penelitian

\section{METODE PENELITIAN}

Dari jumlah total UMKM di DIY pada tahun 2017 (Bappeda Provinsi DIY, 2018) yang tercatat sebanyak 235.313 unit, dengan rincian usaha mikro sebanyak 135.799 unit $(57,7 \%)$, usaha kecil 62.042 unit $(26,3 \%)$ dan usaha menengah 37.472 unit (15,9\%) belum ada data yang menunjukkan jumlah UMKM di DIY yang sudah menggunakan TIK. Dengan demikian, jumlah elemen populasi tidak dapat diketahui.

Sampel penelitian ditentukan dengan nonprobability sampling menggunakan metode purposive dan snowball sampling. Purposive sampling digunakan untuk memperoleh informasi dari kelompok sasaran tertentu yang dapat memberikan informasi yang diinginkan karena mereka satu-satunya pihak yang memiliki atau karena mereka sesuai dengan beberapa kriteria yang ditetapkan oleh peneliti (Sekaran \& Bougie, 2013). Sampel diambil dari populasi pengusaha UMKM di DIY dengan kriteria unit usaha yang sudah menggunakan TIK

Muhammad Muthahhari ${ }^{1}$, Heru Kurnianto Tjahjono ${ }^{2}$, Meika Kurnia Puji RDA ${ }^{3}$ - Niat Penggunaan Teknologi Informasi Dan Komunikasi... [Vol 11, No 1 (2020): April 2020] JBTI 
dalam menjalankan bisnis. Snowball sampling digunakan untuk menemukan responden yang sesuai berdasarkan jejaring pertemanannya hingga memenuhi jumlah yang ditentukan (Salganik \& Heckathorn, 2004). Dalam penelitian ini, peneliti menjadikan responden awal sebagai referen untuk mencari sampel berikutnya, yaitu UMKM yang sudah menggunakan TIK.

Jumlah sampel ditetapkan dengan mengacu pada pendapat (Ghozali, 2017) yang menyatakan syarat harus dipenuhinya jumlah sampel jika menggunakan analisis Structural Equation Model (SEM) dengan metode maximum likelihood (ML). Berdasarkan pendapat tersebut ukuran sampel antara 100 sampai 200 harus digunakan untuk metode estimasi ML. Sample sebanyak 200 dipilih dengan mempertimbangkan tingkat kepercayaan sebesar 95\% dengan margin of error sebesar 7\%. Kriteria tersebut sudah dapat diterima pada penelitian sosial (Rajaretnam, 2016).

Metode survei menggunakan kuesioner on-line dipilih karena kelebihannya, yaitu: lebih murah, lebih baik, lebih cepat, dan lebih mudah daripada metode lain (Schonlau et al., 2002). Kuesioner dikembangkan dengan mengacu pada studi sebelumnya. Skala likert (1-5) mulai dari 'sangat setuju' hingga 'sangat tidak setuju' digunakan untuk semua item yang dikonstruksi kecuali untuk item yang mengukur perilaku penggunaan di bagian pertama. Responden diminta untuk menilai ekspektasi mereka tentang penggunaan TIK dalam bisnis mereka. Responden target untuk penelitian ini adalah pemilik UMKM di Yogyakarta. Dalam studi ini, UMKM mengacu pada bisnis yang memiliki kurang dari 100 karyawan, aset kurang dari Rp10 miliar dan total penjualan per tahun di bawah Rp 50 miliar. Dari 172 kuesioner yang diterima, hanya 164 yang dianggap fungsional. Dari responden tersebut, $50(30,1$ persen) adalah laki-laki dan 114 (69,5 persen) adalah perempuan. Jumlah terbanyak adalah rentang usia 25-34 tahun.

\section{HASIL DAN PEMBAHASAN}

Untuk meneliti hubungan antara variabel independen dengan variabel dependen, digunakan pemodelan persamaan struktural. Sebelum melakukan analisis ini, tes mengenai data outlier, multikolinieritas, dan normalitas dilakukan untuk memastikan data yang digunakan dalam penelitian ini memenuhi persyaratan. Peneliti menjalankan pengukuran dalam bentuk dua model. Model pertama mencakup tiga variabel independen dan satu variabel dependen. Model lain menjalankan satu variabel moderasi.

\section{Reliabilitas}

Berdasarkan rumus reliabilitas konstruk (CR) dan variance extracted (VE) (Hair et al., 2014), hasil VE dan CR dihitung. CR pada semua konstruksi lebih besar dari 0,70 (dari 0,85 ke 0,90). Output VE pada semua konstruksi lebih tinggi dari 0,5 (berkisar 0,59-0,81). Dengan demikian, hasil ini terbukti mendukung keandalan penelitian ini.

\section{Goodness of fit}

Hasil model struktural menunjukkan bahwa model tersebut mencapai tingkat fit yang baik, chi-square $=130,320$, chi-square $/ \mathrm{df}=79, \mathrm{GFI}=0,890, \mathrm{AGFI}=0,834$, TLI $=0,961$, $\mathrm{CFI}=0,971$, RMSEA $=0,066$.

\section{Structural model testing}

Performance expectancy memiliki efek positif dan signifikan pada niat perilaku pada penggunaan TIK untuk bisnis UMKM. Kesimpulannya didasarkan pada nilai-t atau C.R $(2,657 \geq 1,967)$ dan nilai $\mathrm{P}(0,008 \leq 0,05)$. Niat perilaku menggunakan TIK untuk bisnis di

Muhammad Muthahhari ${ }^{1}$, Heru Kurnianto Tjahjono ${ }^{2}$, Meika Kurnia Puji RDA ${ }^{3}$ - Niat Penggunaan Teknologi Informasi Dan Komunikasi... [Vol 11, No 1 (2020): April 2020] JBTI 
UMKM dapat ditingkatkan melalui Performance expectancy. Semakin tinggi ekspektasi UKM bahwa TIK dapat meningkatkan kinerja bisnis, niat untuk menggunakan TIK untuk bisnis akan meningkat. Effort expectancy memiliki efek positif dan signifikan pada niat perilaku pada penggunaan teknologi informasi untuk bisnis UMKM. Kesimpulannya didasarkan pada nilai-t atau C.R $(2,768 \geq 1,967)$ atau nilai $\mathrm{P}(0,006 \leq 0,05)$. Ini berarti bahwa niat untuk menggunakan TIK untuk bisnis di UMKM dapat ditingkatkan melalui Effort expectancy. Semakin tinggi ekspektasi UMKM mengenai kemudahan menggunakan TIK, niat untuk menggunakannya akan meningkat. Social influence tidak secara signifikan mempengaruhi niat perilaku pada penggunaan teknologi informasi untuk bisnis UMKM. Kesimpulannya didasarkan pada nilai-t atau C.R. $(1,680 \leq 1,967)$ dan nilai $\mathrm{P}(0,093 \geq 0,05)$. Artinya, tinggi rendahnya niat menggunakan TIK untuk bisnis di UMKM tidak dipengaruhi oleh Social influence.

\section{Efek moderasi}

Metode penghitungan variabel moderasi dalam program SEM yang digunakan dalam penelitian ini adalah metode Ping. Metode Ping menggunakan indikator tunggal dari perkalian antara indikator variabel laten eksogen dan indikator variabel moderator sebagai indikator variabel pemoderasi (Ghozali, 2017). Hasil perhitungan model dengan variabel moderasi pada hubungan antar variabel dapat dilihat pada tabel di bawah ini:

Tabel 1. Pengujian Efek Moderasi

\begin{tabular}{|c|r|r|r|c|}
\hline Hubungan & Est. & \multicolumn{1}{|c|}{ S.E. } & C.R. & P \\
\hline PE -> BI & .005 & .001 & 4.051 & $* * *$ \\
\hline EE -> BI & .005 & .001 & 5.114 & $* * *$ \\
\hline SI -> BI & .003 & .001 & 3.461 & $* * *$ \\
\hline
\end{tabular}

Berdasarkan hasil tersebut dapat disimpulkan bahwa variabel interaksi pada PE, EE, dan SI memiliki pengaruh yang signifikan terhadap nilai-P *** (di bawah 0,05 ) atau CR lebih besar dari 1,96. Dapat disimpulkan bahwa kecenderungan untuk bertindak memoderasi hubungan antara PE, EE dan SI dengan niat perilaku. Propensity to act memoderasi hubungan performance expectancy dengan niat perilaku dalam penggunaan teknologi informasi untuk bisnis UMKM. Kesimpulannya didasarkan pada nilai-t atau C.R (4.051 $\geq$ 1.967) atau nilai $\mathrm{P}(* * * \leq 0,05)$. Ini berarti bahwa pengaruh ekspektasi kinerja pada niat untuk menggunakan TIK akan lebih besar dalam kondisi pemilik bisnis yang memiliki kecenderungan untuk bertindak, dibandingkan dengan pemilik bisnis yang tidak memiliki kecenderungan untuk bertindak.

Propensity to act memoderasi hubungan effort expectancy dengan niat perilaku dalam penggunaan teknologi informasi untuk bisnis UMKM. Kesimpulannya didasarkan pada nilait atau C.R. $(5,114 \geq 1,967)$ dan nilai $\mathrm{P}(* * * \leq 0,05)$. Artinya, efek dari ekspektasi upaya pada niat untuk menggunakan TIK akan lebih besar dalam kondisi pemilik bisnis yang memiliki kecenderungan untuk bertindak, dibandingkan dengan pemilik bisnis yang tidak memiliki kecenderungan untuk bertindak. Propensity to act memoderasi hubungan social influence pada niat perilaku pada penggunaan teknologi informasi untuk bisnis UMKM. Kesimpulannya didasarkan pada nilai-t atau C.R $(3,461 \geq 1,967)$ dan nilai P $(* * * \leq 0,05)$. Ini berarti bahwa pengaruh sosial pada niat untuk menggunakan TIK akan lebih besar dalam kondisi pemilik bisnis yang memiliki kecenderungan untuk bertindak, dibandingkan dengan pemilik bisnis yang tidak memiliki kecenderungan untuk bertindak. Tabel 2 di bawah ini menyajikan hasil pengujian hipotesis.

Muhammad Muthahhari ${ }^{1}$, Heru Kurnianto Tjahjono ${ }^{2}$, Meika Kurnia Puji RDA ${ }^{3}$ - Niat Penggunaan Teknologi Informasi Dan Komunikasi... [Vol 11, No 1 (2020): April 2020] JBTI 
Tabel 2. Pengujian Hipotesis

\begin{tabular}{|c|l|r|r|r|r|c|}
\hline \multicolumn{2}{|c|}{ Hypothesis } & \multicolumn{1}{c|}{$\boldsymbol{E s t .}$} & \multicolumn{1}{c|}{$\boldsymbol{S . E .}$} & \multicolumn{1}{c|}{$\boldsymbol{C . R .}$} & \multicolumn{1}{c|}{$\boldsymbol{P}$} & Diterima \\
\hline $\mathrm{H} 1$ & PE $\rightarrow$ BI & .276 & .104 & 2.657 & .008 & Ya \\
\hline H2 & EE $\rightarrow$ BI & .233 & .084 & 2.768 & .006 & Ya \\
\hline H3 & SI $\rightarrow$ BI & .110 & .065 & 1.680 & .093 & Tidak \\
\hline H4 & PTA x PE $\rightarrow$ BI & .005 & .001 & 4.051 & $* * *$ & Ya \\
\hline H5 & PTA x EE $\rightarrow$ BI & .005 & .001 & 5.114 & $* * *$ & Ya \\
\hline H6 & PTA x SI $\rightarrow$ BI & .003 & .001 & 3.461 & $* * *$ & Ya \\
\hline
\end{tabular}

Berdasarkan penjelasan di atas, dapat dilihat bahwa adopsi TIK oleh UMKM dipengaruhi oleh beberapa faktor. Pentingnya performance expectancy dalam mendorong penggunaan TIK dalam UMKM menunjukkan bahwa para pemangku kepentingan harus terus mempromosikan manfaat menggunakan TIK untuk menjalankan bisnis, terutama di kalangan anak muda sebagai pengguna terbanyak saat ini. Penelitian lebih lanjut dapat dilakukan untuk mengidentifikasi apakah pengusaha muda lebih menyukai manfaat tertentu dari penggunaan TIK yang tidak dianggap perlu oleh pengusaha yang lebih tua. Manfaat ini harus dikomunikasikan kepada pengguna muda melalui berbagai saluran seperti internet dan iklan. Pemilik usaha kecil harus memahami bahwa mereka memiliki peluang yang sama dalam meningkatkan kinerja bisnis melalui penggunaan TIK.

Stakeholder harus memastikan bahwa penggunaan TIK dalam UMKM dapat dengan mudah dipahami, dipelajari dan digunakan. Kesulitan dalam penggunaan TIK mungkin menjadi hambatan bagi praktisi UMKM yang lebih tua. Pemilik usaha yang berasal dari berbagai latar belakang dan tingkat pendidikan mungkin tidak memiliki basis pengetahuan yang sama dalam hal penggunaan TIK. Mereka yang belum menguasai TIK akan merasakan upaya yang lebih besar dalam mengadopsi TIK. Harapan dari upaya ini dapat ditingkatkan dengan memberikan informasi dan pelatihan. Pakar yang lebih berpengetahuan tentang TIK mungkin bisa menjadi mentor dan membantu mereka yang belum menguasai TIK, menghasilkan transfer pengetahuan dan pengalaman pengguna.

\section{KESIMPULAN DAN SARAN}

Studi ini menemukan bahwa sebagian besar pemilik bisnis yang menggunakan TIK dalam bisnis mereka adalah generasi muda dari mulai di bawah 25 tahun hingga usia 35 tahun. Generasi ini diakui lebih mengerti teknologi dan memiliki kemungkinan lebih besar untuk menggunakan aplikasi TIK. Ini didukung oleh perilaku banyak konsumen muda yang berbelanja melalui toko elektronik, semakin banyak konsumen yang menggunakan TIK juga akan menjadi daya tarik bagi bisnis yang menawarkan produk dan layanan menggunakan TIK. Stakeholder tidak hanya mendorong konsumen untuk berbelanja menggunakan TIK tetapi juga harus mendorong pemilik bisnis untuk menjalankan bisnis mereka menggunakan TIK, terutama yang berasal dari generasi muda.

Penelitian di masa depan di bidang ini dapat dilakukan pada ukuran responden yang lebih besar dan area yang lebih luas. Dimungkinkan juga untuk melakukan penelitian lebih lanjut tentang kelompok pengguna tertentu yang berbeda dalam hal demografi, misalnya membandingkan orang muda dengan yang lebih tua atau membandingkan UMKM pengguna TIK dengan non-pengguna TIK. Analisis statistik juga dapat dilengkapi dengan observasi formal dan wawancara dengan pengguna dan bukan pengguna, pendekatan ini dapat memberikan hasil analisis yang lebih dalam. Potensi bias terkait bias persepsional dan isu common method variance menjadi perhatian yang lebih hati-hati dalam penelitian ke depan.

Muhammad Muthahhari ${ }^{1}$, Heru Kurnianto Tjahjono ${ }^{2}$, Meika Kurnia Puji RDA ${ }^{3}$ - Niat Penggunaan Teknologi Informasi Dan Komunikasi... [Vol 11, No 1 (2020): April 2020] JBTI 


\section{DAFTAR PUSTAKA}

DBS Group Research. (2014). Asian Gamechangers Sink or Swim Business Impact of Digital Technology. Singapore: DBS Asian Insights.

Fobang, A. N., Wamba, S. F., Robert, J., \& Kamdjoug, K. (2017). Exploring Factors Affecting the Adoption of HRIS in SMEs in a Developing Country: Evidence from Cameroon. 1(April).

Ghozali, I. (2017). Model Persamaan Struktural Konsep dan Aplikasi dengan Program AMOS 24 (7th ed.). Semarang: Badan Penerbit Universitas Diponegoro.

Goswami, A., \& Dutta, S. (2017). E-Commerce Adoption by Women Entrepreneurs in India: An Application of the UTAUT Model. Business and Economic Research, 6(2), 440. https://doi.org/10.5296/ber.v6i2.10560

Hair, J. F., Black, W. C., Babin, B. J., \& Anderson, R. E. (2014). Multivariate Data Analysis (7th ed.). Essex: Pearson Education Limited.

Hashim, J. (2007). Information Communication Technology ( ICT ) Adoption Among SME Owners in Malaysia. International Journal of Business and Information, 2(2), 221-240. https://doi.org/10.5897/AJBM10.1398

Internet World Stats. (2019). Asia Internet Stats by Country and 2019 Population Statistics. Retrieved from http://www.internetworldstats.com/asia.htm\#id

Kohnke, A., Cole, M. L., \& Bush, R. (2014). Incorporating UTAUT predictors for understanding home care patients' and clinician's acceptance of healthcare telemedicine equipment. Journal of Technology Management and Innovation, 9(2), 29-41. https://doi.org/10.4067/S0718-27242014000200003

Krueger, N. F., \& Brazeal, D. V. (1994). Entrepreneurial Potential and Potential Entrepreneurs. Entrepreneurship Theory and Practice, 91-104.

Moghavvemi, S., \& salleh, N. A. M. (2014). Malaysian entrepreneurs propensity to use IT innovation. Journal of Enterprise Information Management, 27(2), 139-157. https://doi.org/10.1108/JEIM-05-2012-0026

Palupi, M. \& Tjahjono, H.K. (2008). Aplikasi technology acceptance model (TAM) dengan mempertimbangkan gender pada perilaku penggunaan internet. Jurnal Ekonomi dan Bisnis

Salganik, M. J., \& Heckathorn, D. D. (2004). Sampling and Estimation in Hidden Populations Using Respondent-Driven Sampling. Sociological Methodology, 34(2004), 193-239.

Schonlau, M., Fricker, R. D., \& Elliott, M. (2002). Conducting Research Serveys Via Email and Web. California: RAND.

Sekaran, U., \& Bougie, R. (2013). Research methods for business (6th ed.). New York: John Wiley \& Sons, Inc.

Tan, K. S., Chong, S. C., \& Lin, B. (2013). Intention to Use Internet Marketing: A Comparative Study Between Malaysians and South Koreans. Kybernetes, 42(6), 888905. https://doi.org/10.1108/K-12-2012-0122

Tjahjono, H. K., Maryati, T., \& Fauziyah, F. (2013). Intensi Mahasiswa Yogyakarta Berwirausaha Berbasis Teknologi Informasi (Ti). Jurnal Siasat Bisnis, 17(1), 17-27. https://doi.org/10.20885/jsb.vol17.iss1.art2

Tjahjono, H.K. \& Palupi, M. (2014). Model komseptual intensi berwirausaha berbasis teknologi informasi. Jurnal Bisnis: Teori dan Implementasi,5(1):1-10

Venkatesh, V., Morris, M. G., Davis, G. B., \& Davis, F. D. (2003). User Acceptance of Information Technology: Toward a Unified View. MIS Quarterly, 27(3), 425-478.

Vrsajkovic, D. (2016). Evaluating Determinants of Cloud Computing Acceptance in Croatian

Muhammad Muthahhari ${ }^{1}$, Heru Kurnianto Tjahjono ${ }^{2}$, Meika Kurnia Puji RDA ${ }^{3}$ - Niat Penggunaan Teknologi Informasi Dan Komunikasi... [Vol 11, No 1 (2020): April 2020] JBTI 
SME Organizations. Rochester Institute of Technology.

Wymer, S. A., \& Regan, E. A. (2005). Factors Influencing e-commerce Adoption and Use by Small and Medium Businesses. Electronic Markets, 15(4), 438-453.

Muhammad Muthahhari ${ }^{1}$, Heru Kurnianto Tjahjono ${ }^{2}$, Meika Kurnia Puji RDA ${ }^{3}$ - Niat Penggunaan Teknologi Informasi Dan Komunikasi... [Vol 11, No 1 (2020): April 2020] JBTI 